\title{
ANALISIS KANDUNGAN PEMANIS BUATAN SIKLAMAT PADA SIRUP YANG BEREDAR DIPASAR BESAR MALANG SECARA KUANTITATIF MENGGUNAKAN METODE SPEKTROFOTOMETRI UV-VIS
}

\author{
Maritha Hernaningsih ${ }^{1}$, Lukky Jayadi ${ }^{2}$ \\ ${ }^{12}$ Politeknik Kesehatan Kementerian Kesehatan Malang \\ Email korespondensi: 1ukky.jayadi@gmail.com
}

\begin{abstract}
ABSTRAK
Pemanis merupakan senyawa kimia yang sering ditambahkan dan digunakan untuk keperluan produk olahan pangan industri serta minuman dan makanan, pemanis terdiri dari pemanis alami dan pamanis sintetis, salah satu pemanis sintetis adalah natrium siklamat. Penelitian ini bertujuan untuk mengidentifikasi dan mengetahui kadar natrium siklamat dalam sirup dengan metode spektrofotometri UV dan untuk mengetahui kadar natrium siklamat pada sirup masih aman dikonsumsi. Jenis penelitian adalah eksperimen dan deskriftif. Sampel penelitian yang digunakan adalah sirup yang dijual di pasar besar Kota Malang. Metode yang digunakan untuk penentuan kadar natrium siklamat dilakukan secara Spektrofotometri UV yang serapannya diukur pada panjang gelombang maksimum $314 \mathrm{~nm}$. Hasil penelitian dari analisa kuantitatif terdapat sampel positif mengandung natrium siklamat yaitu sampel 1, 2 dan 3. Hasil penetapan kadar pada sampel 1 sebesar 238,78 mg/kg, sampel 2 sebesar 239,65 mg/kg dan sampel 3 sebesar $241,39 \mathrm{mg} / \mathrm{kg}$. Dari ketiga sampel yang di uji kadar siklamat dalam sirup yang dijual di pasar besar Kota Malang, masih memenuhi syarat yang ditetapkan kepala badan pengawas obat dan makanan.
\end{abstract}

Kata kunci: Sirup, Natrium Siklamat, Spektrofotometri UV-Vis. 


\title{
ANALYSIS OF CYCLAMATE ARTIFICIAL SWEETENER CONTENT IN SYRUP CIRCULATING IN THE BIG MARKET OF MALANG QUANTITATIVELY USING UV-VIS SPECTROPHOTOMETRY METHOD
}

\begin{abstract}
Sweeteners are chemical compounds that are often added and used for industrial food processing products as well as beverages and foods, sweeteners consist of natural sweeteners and synthetic sweeteners, one of the synthetic sweeteners is sodium cyclamate. This study aims to identify and determine the level of sodium cyclamate in syrup by UV spectrophotometry method and to determine the level of sodium cyclamate in syrup is still safe for consumption. The type of research is experimental and descriptive. The research sample used is a syrup which is sold in the big market of Malang City. The method used for the determination of sodium cyclamate levels was done by UV spectrophotometry whose absorption was measured at a greatest wavelength of $314 \mathrm{~nm}$. The results of the quantitative analysis showed that there were positive samples containing sodium cyclamate, sample 1, 2 and 3. The assay results in sample 1 were $238.78 \mathrm{mg} / \mathrm{kg}$, sample 2 was $239.65 \mathrm{mg} / \mathrm{kg}$ and sample 3 was $241.39 \mathrm{mg} / \mathrm{kg}$. Of the three samples tested for levels of cyclamate in syrup sold in the big market in Malang City, they still meet the requirements set by the head of the Food and Drug Supervisory Agency.
\end{abstract}

Keywords: Syrup, Sodium Cyclamate, UV-Vis Spectrophotometry.

\section{PENDAHULUAN}

Minuman ringan adalah minuman yang tidak mengandung alkohol, merupakan minuman olahan dalam bentuk bubuk atau cair yang mengandung bahan tambahan baik alami maupun sintetis yang dapat ditemukan di toko-toko minuman dan makanan. Pemanis sintetis yang umumnya digunakan industri makanan maupun minuman adalah siklamat. Sakarin dan sodium siklamat, merupakan pemanis buatan yang banyak digunakan. Penggunaan sakarin beresiko kanker pada hewan percobaan tikus pada dosis tinggi, 
namun penggunaan pada manusia tidak. Sedangkan siklamat merupakan pemanis buatan dengan tingkat kemanisan 30-40 kali lebih besar dari sukrosa. Potensi karsinogenik siklamat terjadi apabila terkonversi menjadi cyclohexylamine dalam saluran pencernaan. Cyclohexylamine bersifat toksik dan merupakan perangsang (promotor) tumor. (Setiawan, Nuh Ibrahim, \& Wahab, 2016). Hasil penelitian oleh Syahrul dkk menunjukkan bahwa sembilan makanan jajanan negatif mengandung perwarna rhodamin B dan zat methanyel yellow, satu sampel yang mengandung zat pemanis buatan jenis Sakarin, dan dua yang positif mengandung zat pemanis buatan jenis Siklamat serta sembilan jajanan makanan negatif mengandung zat pengawet buatan jenis zat formalin dan jenis zat benzoat. (Syahrul; M. Dachlan, Djunaidi; Virani, 2017)

Pengunaan pemanis buatan di Indonesia masih dapat diizinkan pada makanan dan minuman yang diatur dalam Peraturan Menteri Kesehatan RI No.033/Menkes/Per/2012 Mengenai Bahan Tambahan Makanan. Jenis pemanis buatan yang diperbolehkan Permenkes yaitu Siklamat, Sakarin, Aspartam dan Sorbitol (Hartono, 2014). Analisis siklamat secara kuantitatif digunakan untuk menentukan kadar pemanis siklamat dalam sampel minuman sirup dapat menggunakan Spektrofotometer UV-Vis. Analisis kuantitatif yaitu penentuan kadar siklamat dilakukan dengan mengukur serapan sampel dan panjang gelombang maksimum dengan menggunakan metode spektrofotometer UV-Vis. Dipilihnya metode Spektrofotometer ini dikarenakan metode ini memiliki keunggulan, diantaranya: sensitif, dapat mengukur sampel pada konsentrasi yang kecil, serta volume sampel yang diukur juga kecil (Rasyid, R Melly, dan Mahyuddin, 2011).

Mengonsumsi sakarin secara berlebihan dapat menimbulkan efek samping, diantaranya adalah migrain dan sakit kepala, kehilangan daya ingat, bingung, insomania, iritasi, asma, hipertensi, diare, sakit perut, alergi, impotensi dan gangguan seksual, kebotakan, serta kanker otak dan kandung kemih. Batas maksimum penggunaan sakarin berdasarkan kategori pangan gula dan sirup lainnya yaitu $500 \mathrm{mg} / \mathrm{kg}$ (SNI 01-6993-2004). Berdasarkan hasil penelitian (Fatimah, Arisandi, dan Yunanto, 2015), diketahui dari 12 sampel yang mengandung pemanis buatan sakarin terdapat 3 sampel yang memiliki kadar sakarin tidak memenuhi syarat SNI 016993-2004.

Keamanan pangan merupakan syarat penting yang harus ada pada pangan yang 
akan dikonsumsi oleh manusia. Pangan yang bermutu dan aman dikonsumsi bisa berasal dari dapur rumah tangga maupun dari industri pangan. Oleh karena itu, industri pangan adalah salah satu faktor penentu berkembangnya pangan yang memenuhi standart mutu dan keamanan yang telah ditetapkan oleh pemerintah. Banyak bahan-bahan yang ditambahkan ke dalam makanan dan minuman, sebagai contoh rodhamin B yang banyak digunakan untuk pewarna dan natrium benzoat digunakan untuk bahan pengawet terhadap makanan dan minuman (Nasution,2014).

\section{METODE PENELITIAN}

Penelitian ini dilaksanakan pada bulan April-juni 2021 dimulai dari kegiatan persiapan, pelaksanaan penelitian, dan analisis data di Laboratorium Kimia Universitas Islam Malang. Jenis penelitian yang digunakan pada penelitian adalah deskriftif, yakni peneliti melakukan pengujian laboratorium pada sirup yang mengandung Pemanis buatan Siklmat yang dijual di pasar Besar Malang dan membandingkan hasil penelitian dengan hasil penelitian sebelumnya yang telah dipublikasikan, yang terdapat batas maksimum dalam penggunaanya dengan melakukan analisis metode spektrofotometri uv-vis. Kriteria inklusi dalam penelitian ini adalah kadar pemanis buatan siklamat pada minuman sirup dan kriteria eksklusi adalah minuman sirup yang beredar di pasar yaitu, sirup 1, 2 dan 3.

\section{Alat dan Bahan}

Alat

Alat yang digunakan antara lain: Gelas Ukur, Corong Pisah, Pipet Tetes, Batang pengaduk, Tabung Reaksi, Batang statif dan klem, Pipet volumetric, Labu Ukur, Bola hisap, Timbangan Analitik, Spektrofotometer UV-Vis Genesys 150

\section{Bahan}

Bahan yang digunakan antara lain: Air, Baku Siklamat, Akuades, Asam Klorida 10\%, Asam Sulfat Pekat, Asam Sulfat $30 \%$, etil asetat, Natrium Hidroksida 10 N, Natrium Hidroksida 0,5 N, Sikloheksana, Natrium Hipoklorit

\section{Prosedur kerja}

\section{Pengambilan sampel}

Pengambilan sampel dilakukan pada pedagang minuman sirup di pasar besar Kota Malang. Sampel yang di ambil adalah sirup. Selanjutnya sampel di uji kandungan pemanis buatan siklamat di Laboratorium menggunakan metode Spektrofotometri Uv-Vis.

\section{Metode Analisis}

a. Pembuatan larutan standar dan

\section{Kurva Kalibrasi}

https://doi.org/10.33759/jrki.v3i3.184 
Larutan standar siklamat dibuat dengan konsentrasi 1000 ppm dilakukan dengan menimbang $50 \mathrm{mg}$ siklamat, kemudian dimasukkan ke dalam labu ukur $50 \mathrm{~mL}$ akuades. Larutan standar siklamat dilakukan pengenceran sehingga konsentrasi larutan menjadi 20, 40, 80, 120 dan 160 ppm dengan mengambil $1 \mathrm{~mL}$ untuk 20 ppm, $2 \mathrm{~mL}$ untuk 40 ppm, $4 \mathrm{~mL}$ untuk 80 ppm, $6 \mathrm{~mL}$ untuk 120 ppm, dan 8 mL untuk 160 ppm.

Masing-masing larutan tersebut dipindahkan ke dalam corong pisah pertama, ditambah dengan $1 \mathrm{~mL} \mathrm{NaOH} 10$ N, 5 mL sikloheksana lalu dikocok selama 1 menit. Lapisan air dipisahkan dan dimasukkan ke dalam corong pisah kedua, kemudian ditambahkan dengan 2,5 mL $\mathrm{H} 2 \mathrm{SO} 430 \%, 5 \mathrm{~mL}$ sikloheksana, dan 5 $\mathrm{mL}$ larutan $\mathrm{NaOCl}$, dikocok selama 2 menit. Lapisan sikloheksana (lapisan atas) akan berwarna kuning kehijauan, bila tidak berwarna ditambahkan lagi larutan $\mathrm{NaOCl}$ $\pm 5 \mathrm{~mL}$. Lapisan air dibuang. Kemudian lapisan sikloheksana dicuci dengan $25 \mathrm{~mL}$ $\mathrm{NaOH}$ 0,5 $\mathrm{N}$ dan dikocok selama 1 menit dan lapisan bawah dibuang, lapisan sikloheksana dikocok dengan $25 \mathrm{~mL}$ air, diambil lapisan sikloheksana dan lapisan air dibuang (larutan A).

\section{b. Penentuan panjang gelombang maksimum}

Diukur absorbansi masing-masing konsentrasi pada spektrofotometer UVVis pada panjang gelombang 300-320 nm. Kurva standar dibuat antara konsentrasi terhadap serapan sehingga diperoleh persamaan regresi yang dipergunakan untuk perhitungan pada analisis selanjutnya.

\section{c. Uji Kuantitatif Kadar Siklamat dengan UV-Vis pada sampel (SNI 01-6993-2004)}

Dipipet sampel sebanyak $50 \mathrm{~mL}$ dimasukkan ke dalam corong pisah pertama, ditambah dengan 2,5 $\mathrm{mL}$ H2SO4pekat dan didinginkan. Setelah dingin ditambah dengan $50 \mathrm{~mL}$ etil asetat dikocok selama 2 menit dan diambil \pm 40 $\mathrm{mL}$ bagian yang jernih kemudian dimasukkan ke dalam corong pisah kedua diekstraksi dengan $15 \mathrm{~mL}$ air yang dilakukan dengan 3 kali pengulangan dan dimasukkan ke dalam corong pisah ke-tiga ditambahkan dengan $1 \mathrm{~mL} \mathrm{NaOH} 10 \mathrm{~N}$ dan $5 \mathrm{~mL}$ sikloheksana, dikocok selama satu menit. Lapisan atas dibuang, lapisan air dimasukkan ke dalam corong pisah keempat ditambahkan 2,5 mL H2SO430 \%, $5 \mathrm{~mL}$ sikloheksana, dan $5 \mathrm{~mL}$ larutan $\mathrm{NaOCl}$ pa, dikocok selama 2 menit. Lapisan sikloheksana (lapisan atas) akan berwarna kuning kehijauan, bila tidak berwarna ditambahkan lagi larutan $\mathrm{NaOCl}$ $\pm 5 \mathrm{~mL}$. Lapisan air dibuang kemudian 
lapisan sikloheksana dicuci dengan $25 \mathrm{~mL}$ $\mathrm{NaOH}$ 0,5 $\mathrm{N}$ dan dikocok selama 1 menit dan lapisan bawah dibuang, lapisan sikloheksana dikocok dengan $25 \mathrm{~mL}$ air, diambil lapisan sikloheksana dan lapisan air dibuang (larutan B).

\section{d. Larutan Blanko}

Dipipet air sebanyak $50 \quad \mathrm{~mL}$ dimasukkan ke dalam corong pisah pertama, ditambah dengan 2,5 $\mathrm{mL}$ H2SO4pekat dan didinginkan. Setelah dingin ditambah dengan $50 \mathrm{~mL}$ etil asetat dikocok selama 2 menit dan diambil \pm 40 $\mathrm{mL}$ bagian yang jernih. Kemudian dimasukkan ke dalam corong pisah kedua, diekstraksi dengan $15 \mathrm{~mL}$ air yang dilakukan dengan 3 kali pengulangan. Dikumpulkan lapisan air dan dimasukkan ke dalam corong pisah ke-tiga, ditambahkan $1 \mathrm{~mL} \mathrm{NaOH} 10 \mathrm{~N}$ dan $5 \mathrm{~mL}$ sikloheksana, dikocok selama satu menit. Lapisan atas dibuang, lapisan air dimasukkan ke dalam corong pisah keempat ditambahkan 2,5 mL H2SO430\%, $5 \mathrm{~mL}$ sikloheksana, dan $5 \mathrm{~mL}$ larutan $\mathrm{NaOCl}$ pa, dikocok selama 2 menit. Lapisan sikloheksana (lapisan atas) akan berwarna kuning kehijauan, bila tidak berwarna ditambahkan lagi larutan $\mathrm{NaOCl}$ $\pm 5 \mathrm{~mL}$. Lapisan air dibuang kemudian lapisan sikloheksana dicuci dengan $25 \mathrm{~mL}$ $\mathrm{NaOH}$ 0,5 $\mathrm{N}$ dan dikocok selama 1 menit dan lapisan bawah dibuang, kemudian lapisan atas (sikloheksana) dicuci dengan $25 \mathrm{~mL}$ akuades, dikocok dan dipisahkan dan diambil larutan lapisan bagian atas yang digunakan sebagai blanko (larutan C).

\section{e. Penetapan Kadar Siklamat}

Masing-masing larutan A, B diukur menggunakan spektrofotometer pada panjang gelombang maksimum dan larutan C sebagai larutan pembanding, kemudian dihitung kadar pemanis siklamat dengan menggunakan persamaan regresi linear $y=a x \pm b$.

\section{HASIL DAN PEMBAHASAN}

\section{Hasil Panjang Gelombang Maksimum Larutan Siklamat}

Penentuan panjang gelombang maksimum siklamat bertujuan untuk mengetahui daerah serapan maksimum yang dapat dihasilkan berupa nilai absorbansi dari suatu larutan uji. Larutan baku natrium siklamat digunakan untuk panjang gelombang maksimum yaitu konsentrasi 314 ppm kemudian di ukur absorbansinya menggunakan Spektrofotometer UV-Vis pada rentang panjang gelombang 300-320 nm. Hasil panjang gelombang maksimum Larutan Standar

Siklamat. 


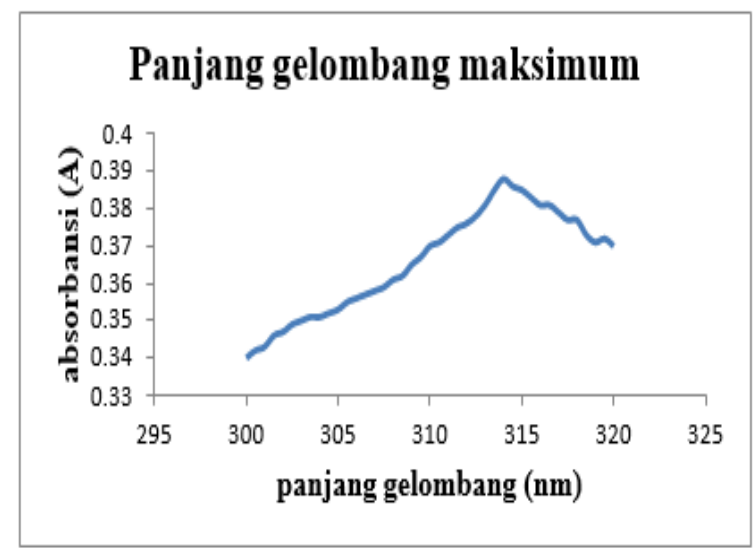

Gambar 1. Kurva Panjang Gelombang Maksimum pada Larutan Standar Siklamat

\section{Kurva Kalibrasi Larutan Baku Natrium Siklamat}

Pada pembuatan larutan baku standar Siklamat, terlebih dahulu dibuat larutan baku induk 1000 ppm, dengan cara menimbang padatan serbuk Siklamat sebanyak $50 \mathrm{mg}$ menggunakan neraca analitik.

Penimbangan dilakukan langsung menggunakan labu ukur $50 \mathrm{ml}$, Padatan tersebut dimasukkan kedalam labu ukur 50 ml dan ditambahakan aquades hingga tanda batas serta dikocok hingga homogen dan dihasilkan larutan berwarna jernih. Dari larutan induk 1000 ppm, kemudian dibuat pengenceran larutan standar yaitu $20,40,80,120$, dan 160 ppm dengan cara memipet larutan standar $100 \mathrm{ppm}, 1 \mathrm{ml}$ untuk 20 ppm, 2 ml untuk 40 ppm, $4 \mathrm{ml}$ untuk 80 ppm, 6 ml untuk 120 ppm, dan 8 $\mathrm{ml}$ untuk 160 ppm dan diencerkan dengan menambahkan aquades hingga tanda batas labu ukur $50 \mathrm{ml}$.

Kemudian mencari kurva kalibrasi dengan memasukkan masing-masing larutan standar tersebut dipindahkan ke dalam corong pisah, lalu ditambah dengan $1 \mathrm{ml} \mathrm{NaOH} 10 \mathrm{~N}, 5 \mathrm{ml}$ sikloheksana lalu dikocok. Lapisan air dipisahkan dan dimasukkan ke dalam corong pisah, kemudian ditambahkan dengan $2,5 \mathrm{ml}$ H2SO4 $30 \%$, $5 \mathrm{ml}$ sikloheksana, dan $5 \mathrm{ml}$ larutan $\mathrm{NaOCl}$ pa, dan dikocok. Kemudian lapisan air dibuang.

Lapisan sikloheksana dicuci dengan 25 $\mathrm{ml} \mathrm{NaOH}$ 0,5 $\mathrm{N}$ dan dikocok selama 1 menit dan lapisan bawah dibuang, lapisan sikloheksana dikocok dengan $25 \mathrm{ml}$ air, diambil lapisan sikloheksana, Selanjutnya dilakukan penentuan panjang gelombang maksimum menggunakan larutan standar yang ditentukan dengan instrument Spektrofotometer UV-Vis dan diperoleh panjang gelombang maksimum sebesar $314 \mathrm{~nm}$.

Dari analisis tersebut dihasilkan kurva linearitas, sehingga absorbansi larutan standar 20, 40, 80, 120, 160 ppm yang dihasilkan mempunyai koefisien korelasi yang bagus yaitu 0,9939. Table nilai absorbansi dari larutan standar siklamat 
pada panjang gelombang maksimum 314 nm.

Tabel 1. Konsentrasi dan Absorbansi Siklamat pada sirup Berdasarkan Spektrofotometer UV-Vis

\begin{tabular}{cc}
\hline $\begin{array}{c}\text { Konsentrasi } \\
(\mathbf{p p m})\end{array}$ & Absorbansi (A) \\
\hline 20 & 0,065 \\
40 & 0,100 \\
80 & 0,220 \\
120 & 0,305 \\
160 & 0,385 \\
\hline
\end{tabular}

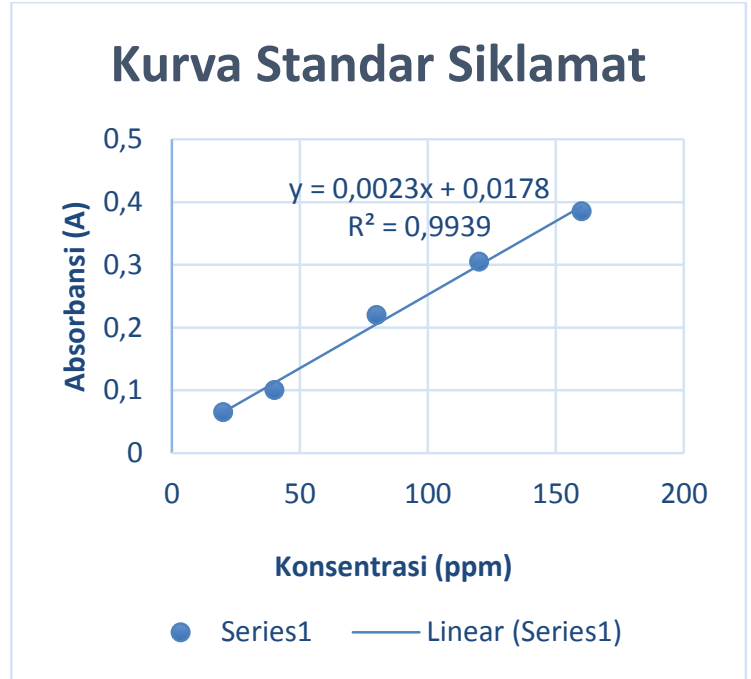

Gambar 2. Kurva Kalibrasi Larutan Standar Siklamat

\section{Hasil Kuantitatif Metode Spektrofotometri}

Analisis kuantitatif siklamat yang dilakukan pada 3 sampel sirup di kawasan pasar besar Malang. Berdasarkan data yang disajikan pada table 2. menunjukkan bahwa dalam seluruh sampel sirup positif mengandung pemanis siklamat.

Tabel 2. Kandungan Siklamat pada sirup Berdasarkan Spektrofotometer UV-Vis

\begin{tabular}{ccc}
\hline Nama & $\begin{array}{c}\text { Absorbansi } \\
\text { Sampel }\end{array}$ & $\begin{array}{c}\text { Kadar } \\
\text { Siklamat } \\
\text { (mg/kg) }\end{array}$ \\
\hline Sampel & 0,567 & 238,78 \\
sirup 1 & & $\mathrm{mg} / \mathrm{kg}$ \\
Sampel & 0,569 & 239,65 \\
sirup 2 & & $\mathrm{mg} / \mathrm{kg}$ \\
Sampel & 0,573 & 241,39 \\
sirup 3 & & $\mathrm{mg} / \mathrm{kg}$ \\
\hline
\end{tabular}

Pada analisis kadar siklamat dilakukan pengujian dengan metode Spektrofotometer UV-Vis, langkah awal dalam melakukan uji kadar pemanis siklamat dengan cara membuat larutan baku atau larutan standar. Larutan standar adalah larutan yang mengandung konsentrasi yang telah diketahui secara tepat. Sehingga setelah diketahui konsentrasinya maka dilakukan penentuan panjang gelombang maksimum dengan menggunakan Spektrofotometer UV-Vis. Adapun proses dalam pembuatan larutan 
standar siklamat diawali dengan mereaksikan larutan standar dengan $\mathrm{NaOH}$ dan sikloheksana. Larutan $\mathrm{NaOH}$ berfungsi untuk memberikan suasana basa sedangkan sikloheksana sebagai pengekstrak siklamat. Kemudian ekstrak dari siklamat akan direaksikan kembali dengan $\mathrm{H} 2 \mathrm{SO} 4$, sikloheksana, dan $\mathrm{Na}-$ hipoklorit membentuk dua lapisan yaitu lapisan atas larutan sikloheksana jernih dan lapisan bawah jernih tidak berwarna. Lapisan sikloheksana diambil dan dilakukan pencucian dengan $\mathrm{NaOH}$ sehingga membentuk larutan tidak berwarna. Pada lapisan sikloheksana ini siklamat telah terekstrak di dalamnya kemudian diukur absorbansinya menggunakan spektrofotometer UV-Vis. Sedangkan Untuk analisis sampel dan blanko (zat pembanding) dengan cara mereaksikan dengan H2SO4. Tujuan penambahan asam sulfat adalah untuk mengubah siklamat menjadi asam siklamat, kemudian larutan asam siklamat diekstraksi dengan pelarut etil asetat membentuk asam siklamat dalam fase organik dan terdapat dua lapisan tidak berwarna. Selanjutnya asam siklamat diekstraksi dengan akuades sebanyak tiga kali perulangan yang bertujuan untuk mengikat senyawa siklamat yang terdalam dalam sampel secara menyeluruh sehingga terpisah dari komponen sampel. Dengan kata lain, air berfungsi sebagai pelarut dimana air merupakan pelarut yang sering digunakan dalam UV karena air mempunyai penampilan yang transparan pada daerah UV-Vis sehingga tidak terganggu dengan tidak mengabsorbsi cahaya pada saat diananlisa. Kemudian diperlakukan sama seperti larutan standar yang dimulai dengan penambahan $\mathrm{NaOH}$ dan sikloheksana. Selanjutnya diukur sampel menggunakan blanko sebagai pembanding dengan menggunakan panjang gelombang maksimum yang telah didapatkan dari larutan standar.

Penentuan nilai serapan suatu sampel harus berada pada panjang gelombang maksimum, sehingga didapatkan nilai yang maksimal. Pada penelitian ini panjang gelombang maksimum diukur pada kisaran 300-320 $\mathrm{nm}$, dan didapatkan panjang gelombang maksimum $314 \mathrm{~nm}$ berdasarkan nilai absorbansi tertingginya. Kadar pemanis siklamat didapatkan berdasarkan pengukuran serapan dari deretan konsentrasi larutan siklamat pada panjang gelombang maksimum yang menghasilkan persamaan regresi linear yaitu $y=0,0023 x$ $+0,0178$. Panjang gelombang maksimum siklamat tersebut digunakan untuk pembuatan kurva kalibrasi dan penetapan kadar siklamat dalam sampel yang 
dianalisis. Kadar yang diperoleh dari hasil penelitian adalah untuk sampel sirup 1 sebesar 238,78 mg/kg sedangkan sampel sirup 2 sebesar 239,65 mg/kg, dan sampel sirup 3 sebesar 241,39 mg/kg, perhitungan kadar sampel sirup dapat dilihat pada lampiran 4. Hasil yang diperoleh menunjukkan bahwa kadar tersebut tidak melebihi batas standar yang ditetapkan peraturan kepala badan pengawas obat dan makanan Republik Indonesia Nomor 4 tahun 2014 adalah $250 \mathrm{mg} / \mathrm{kg}$ sehingga aman untuk dikonsumsi. Walaupun aman untuk dikonsumsi penggunaan pemanis buatan tidak dianjurkan untuk masyarakat umum karena penggunaan pemanis buatan lebih dikhususkan untuk masyarakat tertentu terutama penderita diabetes yang bertujuan untuk mengontrol kadar gula berlebih atau untuk penderita kegemukan, namun juga harus dalam batas tertentu dan harus diawasi oleh dokter atau ahli kesehatan. Badan Pengawas Obat dan Makanan Republik Indonesia (BPOM RI) juga menyebutkan bahwa pemanis yang dibolehkan untuk ditambahkan ke dalam sirup adalah gula alami, sedangkan untuk pemanis non-kalori tidak diperbolehkan (Musiam, 2016).

Siklamat yang dikonsumsi dalam dosis yang berlebihan dapat memunculkan banyak gangguan bagi kesehatan.
Beberapa gangguan kesehatan tersebut antara lain seperti migrain dan sakit kepala, kehilangan daya ingat, bingung, insomnia, iritasi, asma, hipertensi, diare, sakit perut, alergi, impotensi dan gangguan seksual, serta kebotakan. Siklamat yang dikonsumsi dalam dosis yang berlebihan akan mengakibatkan kanker kandung kemih. Menjaga kesehatan dapat dilakukan dengan banyak cara. Rutin berolah raga, menjaga asupan makanan dan minuman yang mencukupi kebutuhan gizi dalam tubuh adalah salah satu upaya menjaga kesehatan. Menjaga asupan makanan dan minuman dengan gizi cukup pada dewasa ini sulit dilakukan, karena banyak makanan dan minuman yang sudah mengandung bahan tambahan pangan. Bahan tambahan pangan memiliki ciri yang sulit untuk dimetabolisme oleh tubuh apabila kadar yang terkandung dalam tubuh terlalu banyak dan akan menimbulkan penyakit-penyakit kronis pada tubuh, sehingga dalam menjaga asupan bahan tambahan pangan kita harus menghindari makanan dan minuman yang menggunakan bahan tambahan pangan sintesis (Lestari, 2011).

\section{KESIMPULAN}

Kesimpulan dalam penelitian ini adalah Analisis kandungan siklamat pada tiga sampel sirup yang beredar di kawasan 
Pasar Besar Malang, ditemukan adanya pemanis siklamat. Kadar siklamat yang diperoleh pada sampel sirup yang dijual dipasar besar malang tidak melebihi batas maksimum yakni, sampel sirup 1 sebesar $238,78 \mathrm{mg} / \mathrm{kg}$, sampel sirup 2 sebesar $239,65 \mathrm{mg} / \mathrm{kg}$ dan sampel sirup 3 sebesar $241,39 \mathrm{mg} / \mathrm{kg}$, sampel tersebut masih memenuhi syarat mutu.

\section{UCAPAN TERIMAKASIH}

Kepada Allah SWT. Alhamdulillah hirobbil'alamin atas segala rahmat dan hidayahnya serta segala nikmat yang telah diberikan. Terima kasih pada keluarga, teman-teman, dosen, staf sekretariat dan laboratorium atas masukan dan banyak membantu selama proses berlangsung.

\section{DAFTAR PUSTAKA}

Fatimah, S., Arisandi, D., \& Yunanto, D. 2015. Penetapan Kadar Sakarin Minuman Ringan Gelas Plastik Yang Dijual Di Pasar Beringharjo, Yogyakarta. Di dalam: Seminar Nasional Teknologi Kimia, Industri dan Informasi; Yogyakarta. 10 Oktober 2015. STIKES Guna Bangsa, Yogyakarta. 46-56

Hartono, R. 2014. Identifikasi Siklamat Pada Minuman Jajanan Di Kawasan Pendidikan Kota Palangkaraya. Karya Tulis Ilmiah, Fakultas Ilmu
Kesehatan, Universitas

Muhammadiyah Palangka Raya Lestari. D. (2011). Analisis Adanya Kandungan Pemanis Buatan (Sakarin dan Siklamat) pada Jamu Gendong Di Pasar Gubug Grobogan. Skripsi. Fakultas Tarbiyah, Institut Agama Islam Negeri Walisongo. Semarang.

Musiam, S., Hamidah, M., dan Kumalasari, E. (2016). Penetapan Kadar Siklamat dalam Sirup Merah Yang Di Jual Di Banjarmasin Utara. Jurnal Ilmiah Ibnu Sina. Volime 1. No. 1.

Nasution, A. S. (2014). Kandungan Zat Pewarna Sintetis Pada Makanan dan Minuman Jajanan di SDN IX Kelurahan Ciputat Kecamatan Ciputat Kota Tangerang Selatan Tahun 2014.

Rasyid, R., R melly, Y., dan Mahyuddin. (2011). Analisis Pemanis Sintesis Natrium Sakarin dan Natrium Siklamat dalam Teh Kemasan. Jurnal: Farmasi Higea. Volume. 3. No. 1

Setiawan, E. A., Nuh Ibrahim, M., \& Wahab, D. (2016). Analisis Kandungan Zat Pemanis Sakarin Dan Siklamat Pada Minuman Yang Di Perdagangkan Di Sekolah Dasar Di Kelurahan Wua-Wua Kota https://doi.org/10.33759/jrki.v3i3.184 
Kendari. J. Sains Dan Teknologi

Pangan, 1(1), 45-50.

SNI01-6993-2004. Bahan Tambahan

Pangan Pemanis Buatan Dan

Persyaratan Penggunaan. Badan

Standar Nasional Spangenberg, B.,

Poole, C.F., and Weins, C., 2011.

Quantitative ThinLayer

Chromatography: A Practical Survey

Syahrul; M. Dachlan, Djunaidi; Virani, D. (2017). Overview of the using Dye,

Sweeteners and Preservaties in

Snack Foods in Makassar City, 3. 